Aina A. Kane

Førstelektor/cand.jur

UiT Norges Arktiske Universitet

Institutt for barnevern og sosialt arbeid

Modulbygget Campus Troms $\emptyset$

9037 Troms $\emptyset$

aina.a.kane@uit.no

Artikkelens tittel:

Barns menneskerettslige krav på beskyttelse - En sammenligning av juridiske rammer for bekymringsmelding og undersøkelse i Norge og England. 


\title{
Sammendrag
}

Barnets rett til beskyttelse skal ifølge FNs Konvensjon om barnets rettigheter (Barnekonvensjonen 1989) fremmes gjennom både lovgivning og myndighetsutøvelse. Både England og Norge har ratifisert barnekonvensjonen, og har nasjonale lover som skal sikre barnets beskyttelse mot vold og omsorgssvikt gjennom at bekymringsverdige forhold blir meldt fra om og unders $\varnothing \mathrm{kt}$ av ansvarlige myndigheter. Begge land har synliggjort barnets menneskerettigheter i sin lovgivning, herunder prinsipper om barnets beste, lovmessighet, forholdsmessighet og barnets rett til medvirkning.

De to landenes lovgivning har både likheter og forskjeller på disse områdene, og i denne artikkelen sammenlignes disse for å belyse hvordan barnets rett til beskyttelse kan påvirkes av landenes nasjonale lovgivning. I England har foreldre adgang til «rimelig fysisk avstraffelse» av sine barn, mens Norge har forbud mot det. I Norge har yrkesutøvere i velferdstjenester plikt til å opplyse barneverntjenesten om bekymringer for barn, en plikt som ikke finnes i England. Terskelen for igangsettelse av barnevernundersøkelse er høyere i England enn i Norge, samtidig har England mer detaljert rammeverk enn Norge for hvilke områder rundt barnet som skal fokuseres på i en barnevernundersøkelse. Barnets beste, som grunnleggende prinsipp, har en mer fremtredende plassering og er mer detaljert beskrevet i engelsk rett enn i norsk. Hvilke konsekvenser kan de ulike forskjeller ha med hensyn til barnets rett til beskyttelse i de to landene? Dette er hovedspørsmålet som diskuteres i artikkelen.

Nøkkelord: Barn, barnekonvensjonen, beskyttelse, barnevern, bekymringsmelding, unders $\emptyset$ kelse, Children Act, barnevernlov.

\begin{abstract}
The UN Convention on the Rights of the Child (1989) states that the child's right of protection is to be secured through legislation and governance. England and Norway have ratified this convention, and have national legislations, which aim to secure the child's protection against violence and negligence through concerns about the child being reported to and assessed by authorities. Both countries have visualized the child's human rights in their legislations, amongst others principles of the child's welfare/best interests, legality, proportionality and the child's right to be heard.
\end{abstract}

The two countries' legislation shows both similarities and differences within child protection through reports and assessments, and this article compares the legislations in order to enlighten how the child's right of protection is influenced by national legislations. In England, parents have the right to use «reasonable punishment» towards their children, which is banned in Norway. In Norway, professionals are obliged to report concerns about a child to the child protection services - this is not mandatory in England. The threshold for initiating a child protection assessment is higher in England than in Norway, whilst England's framework for assessments is more detailed than Norway's. The Child Welfare/best interest Principle is placed more prominently and described more detailed in the English legislation than in the Norwegian. What are the possible consequences of these differences with regards to the child's right to protection in the two countries? This is the main question to be discussed in this article.

Key words: Children, UN Convention on the rights of the Child, child protection, child referrals, assessement, Children Act, child protection law 


\section{Barns menneskerettslige krav på beskyttelse - En sammenligning av juridiske rammer for bekymringsmelding og undersøkelse i Norge og England.}

\section{Innledning.}

FNs konvensjon om barnets rettigheter av 20. november 1989 (heretter: BK) art. 19 pålegger de tiltrådte stater å sørge for at barn blir beskyttet mot «alle former for fysisk eller psykisk vold, skade eller misbruk, vanskjøtsel eller forsømmelig behandling, mishandling eller utnytting, herunder seksuelt misbruk». Barnets rett til beskyttelse kan komme i konflikt med dets rett til privatliv og familieliv uten ulovlige inngrep fra myndighetene (BK art. 8 og 16) i enkeltsaker, hvor offentlige myndigheter griper i barnets familieliv på grunnlag av bekymring om overgrep eller omsorgssvikt. Barnekonvensjonen er ratifisert av både Norge og Storbritannia (herunder England) i 1991, så landene plikter å ha lovgivning som sikrer barns velferd, samt administrative myndigheter med spesielt ansvar for å ivareta barns behov og rettigheter. I følge BK art. 19(2) bør beskyttelsestiltak omfatte former for «........påpeking, rapportering, viderehenvisning, undersøkelse ..[..]..», det er derfor interessant å sammenligne de to landenes lovbestemmelser som regulerer rapportering av bekymringer rundt et barn, samt undersøkelse av bekymringsverdige forhold. En sammenligning av utvalgte områder i disse to landenes lovgivning kan gi mulige innspill til tydeliggjøring av barnets rett til beskyttelse i norsk barnevernlovgivning. I denne artikkelen skal jeg derfor drøfte noen utvalgte forskjeller i de to landenes lovgivning, i lys av barnets menneskerettslige krav på beskyttelse, ut fra problemstillingen:

\section{Forskjeller i engelsk og norsk barnevernlovgivning om melding og undersøkelse: Konsekvenser for barns menneskerettslige krav på beskyttelse?}

Ved å anvende begrepene «overgrep og omsorgssvikt»s $ø$ ker jeg å dekke de forhold som er beskrevet i BK art. 19. Innledningsvis vil jeg redegjøre for barnets menneskerettslige krav på beskyttelse etter BK, dernest for Englands og Norges lovgivning rundt myndighetenes adgang og plikt til intervensjon for å beskytte barn som opplever eller er i risiko for overgrep og omsorgssvikt. Jeg fremhever så noen forskjeller mellom de to landenes lovgivning, og drøfter hvordan barnets rett til beskyttelse kan påvirkes, gjennom eksempelvis lovers ordlyd og lovtekniske forhold. Noen drøftelser munner ut i konkrete forslag for hvordan barnets rett til beskyttelse på ulike områder kan tydeliggjøres i norsk lovgivning.

Englands og Norges barnevernlovgivning har vært sammenlignet av blant andre Križ og Skivenes (2014), som oppsummerer at begge landenes barnevernssystemer vektlegger 
prinsipper om barnets beste, trygghet, stabilitet og å opprettholde familier. Forfatterne fremhever at barnevernsystemer i Norge vektlegger barnets velferd generelt, mens man i England synes å ha mer spesifikt fokus på barnets sikkerhet. Dette støttes av Samsonsen og Willumsen (2015), som peker på at barnevernlitteratur i liberale land, som for eksempel England, fremhever barnets beskyttelse, mens land med sosialdemokratiske tradisjoner, herunder Norge, har søkelys på barnets velferd i videre forstand. Mitt bidrag søker å vise hvordan barnets rett til beskyttelse avhenger av at bekymringer rundt barnet blir tatt hånd om. Hvordan forholder lovgivningen i de to landene seg til bruk av fysisk avstraffelse i oppdragelsen? Hvilken plikt har yrkesutøvere som arbeider med barn i England og Norge til å melde fra om bekymringsverdige forhold rundt barnet, til ansvarlig barnevernmyndighet? Hvilke terskler foreligger for at den ansvarlige barnevernmyndighet skal unders $\varnothing \mathrm{ke}$ bekymringsverdige forhold rundt barnet? Hvilke fokusområder skal de to landenes barnevernmyndigheter ha i undersøkelsen? Hvordan fremtrer prinsippet om barnets beste i de to landenes lover? For å finne svar på disse spørsmål vil jeg sammenligne de to landenes skrevne lover som regulerer de nevnte områder, og peke på noen forskjeller som kan medføre at barnets rett til beskyttelse fremmes eller hemmes.

\section{Fremgangsmåte og metodiske utfordringer}

Å sammenligne to lands lovgivning innebærer ulike metodiske utfordringer, da rettssystemene og rettskildene er ulikt utformet. Norge har i stor grad skrevne lover fastsatt av lovgivende myndigheter (jfr Grunnloven 17. mai 1814 § 76). I England har «common law», det vil si lovgivning som er etablert gjennom rettsavgjørelser, fortsatt høy relevans (Brayne et al. 2014). Barnevernlovgivningen er likevel hovedsakelig skriftliggjort og har status som «statute law», dvs. er bindende for domstoler og forvaltning. (ibid s. 6). Norge har en skreven grunnlov, mens England forholder seg til en grunnlov som ikke er nedskrevet eller kodifisert. I stedet har England og de andre britiske stater en samling av ulike vedtekter, konvensjoner, rettsavgjørelser og overenskomster som i sum kan refereres til som Den britiske Grunnlov. «It is thus more accurate to refer to Britain's constitution as an 'uncodified' constitution, rather than an 'unwritten' one."’i Ut fra dette bildet velger jeg å sammenligne skrevne lover som regulerer myndighetenes adgang og plikt til å intervenere i familiers privatliv med formålet å beskytte barnet mot overgrep og omsorgssvikt.

I England regulerer The Children Act England and Wales 1989 (heretter: Children Act) både de familierettslige forhold rundt barnet og de offentligrettslige forhold som for eksempel 
barnevernmyndigheters intervensjon samt barnets rett til ulike velferdstjenester. I Norge reguleres de familierettslige forhold av Lov om barn og foreldre av 8. april 1981 (heretter: barnelova), mens barnevernarbeid reguleres av Lov om barneverntjenester 17 juli $1992 \mathrm{nr}$. 100 (heretter: barnevernloven), supplert av Lov om behandlingsmøter i forvaltningssaker av 10. februar 1967 (heretter: forvaltningsloven). Artikkelens mål er ikke å foreta en fullstendig sammenligning av de to landenes lovsystemer og lovgivning på barnevernområdet, men heller å peke på noen likheter og forskjeller som kan bidra til hemme eller fremme barnets rett til beskyttelse gjennom at bekymringsfulle forhold rundt barnet blir avdekket og undersøkt. De rettskilder som vil bli anvendt er i størst grad de formelle lovtekster, supplert av forarbeider, rundskriv og juridisk litteratur som jeg har fortolket. Lovfortolkningsmetoden legger til grunn en forutsetning om at fortolkningen etter etablerte tolkningsprinsipper skal gi et forsvarlig tolkningsresultat, altså om det «ligger innenfor det rettslig mulige og akseptable» (Aasen 2000 s. 124).

Å sammenligne to lands statistikk innebærer også utfordringer, da man ikke registrerer de samme forhold. For eksempel registrerer man i England hvor mange barn som er kategorisert under «in need», mens man i Norge registrerer antall iverksatte barneverntiltak. Kategorien «in need» betegner barn som anses å ha særlige behov for kommunale tiltak og tjenester for å kunne oppnå eller opprettholde en tilfredsstillende helse eller utvikling eller at barnets helse eller utvikling sannsynligvis vil bli nedsatt uten slike tiltak og tjenester (Children Act sec 17). De engelske statistikkene viser dessuten tall fra mars 2013 til mars 2014, mens de norske viser mellom januar og desember 2014.

\section{Barnets menneskerettslige krav på beskyttelse mot vold og omsorgssvikt}

\section{Barnebefolkning og barnevernforvaltning}

I 2014 hadde England 11.591.701 barn under 18 år, hvorav 0,35\% av barna var plassert under kategorien «in need», altså i behov av ulike tiltak og tjenester (397.600 barn). Norge hadde 1.111.494 barn, hvorav 0,75\% av barnebefolkningen mottok barneverntiltak (82.736 barn). I Norge var omlag $15 \%$ av barneverntiltakene omsorgstiltak, og i England tilsvarte antallet barn som var «looked after» (på grunnlag av omsorgsovertakelse eller plassering) ca. 17\%.i Samme år mottok barneverntjenestene i Norge 52.996 meldinger, dvs. en melding pr 21 barn, 
mens Social services i England i perioden mars 2013 - mars 2014 mottok 657.800 meldinger, dvs. en melding pr 17 barn. ${ }^{\text {iii }}$

Menneskerettighetskonvensjoner gjelder alle mennesker, både voksne og barn omfattes av det grunnleggende prinsipp om verdighet og like rettigheter i FNs verdenserklæring om menneskerettigheter av 10. desember 1948, art 1. Barn og deres familier har rett til sitt privatliv og familieliv uten ulovlig innblanding fra myndighetene, jfr. Den Europeiske Menneskerettighetskonvensjon 1950 (heretter EMK) art. 8 og BK art. 8. Samtidig stadfester BK art. 19 at barn krav på statens beskyttelse mot ulike former for vold og omsorgssvikt fra sine omsorgspersoner.

Både England og Norge styres av grunnleggende rettsstatsprinsipper, herunder kravet om lovhjemmel, likebehandling og forholdsmessighet, samt retten til medvirkning og kontradiksjon. (EMK art. 5, 8 og 10). Prinsippene ligger til grunn også for barnevernarbeid, supplert av prinsipper om bevaring av familieforhold og hensynet til barnets beste. (BK art. 3 , $8,16)$. I begge land er det lokale/kommunale forvaltningsorganer som har ansvar for barnevernarbeid i form av mottak av bekymringsmeldinger og gjennomføring av unders $\varnothing$ kelse (Children Act sec 47 (1), barnevernloven $§ 2-1$ ).

\section{FN's barnekonvensjons art 19 om barnets rett til beskyttelse}

Barnekonvensjonens art. 19 (norsk oversettelse):

1. «Partene skal treffe alle egnede lovgivningsmessige, administrative, sosiale og opplæringsmessige tiltak for å beskytte barnet mot «alle former for fysisk eller psykisk vold, skade eller misbruk, vanskjøtsel eller forsømmelig behandling, mishandling eller utnytting, herunder seksuelt misbruk mens en eller begge foreldre, verge(r) eller eventuell annen person har omsorgen for barnet».

2. Slike beskyttelsestiltak bør omfatte effektive prosedyrer for utforming av sosiale programmer som yter nødvendig støtte til barnet og til dem som har omsorgen for barnet, samt andre former for forebygging, påpeking, rapportering, viderehenvisning, undersøkelse, behandling og oppfølging av tilfeller av barnemishandling som tidligere beskrevet og, om nødvendig, for rettslig oppfølging». 
FNs Barnekomité har i sin generelle kommentar nr. 13 (2011) fremhevet at retten til beskyttelse gjelder alle former for fysisk og/eller psykisk vold og ulike former for vanskjøtsel. Begrepet vold anvendes i barnekonvensjonen som en samlebetegnelse for «alle former for skadevoldende atferd mot barn» (2011 s. 4), og omfatter både fysisk vold mot barnet og psykisk vold ved at barnet er vitne til vold mot andre. Videre omfatter psykisk vold ifølge FNs Barnekomité psykiske overgrep, verbal mishandling og emosjonell mishandling eller omsorgssvikt. Barnekomitéen eksemplifiserer vanskjøtsel med unnlatelse av å ivareta barns fysiske og psykiske behov, herunder behov for omsorg i dagliglivet, trygghet, medisinsk behandling og opplæring.

For å ivareta barnets rett til beskyttelse pålegger BK art. 19 (1) de tiltrådte land å treffe bl.a. alle nødvendige lovgivningsmessige og administrative tiltak, og FNs Barnekomité uttaler i sin generelle kommentar nr. 13 (2011 s. 15) at dette innebærer en revurdering av nasjonal lovgivning i tråd med art. 19, samt håndheving av lover og rettslige prosedyrer på en barnevennlig måte. Artikkelens andre ledd fremhever ulike beskyttelsestiltak, herunder påpeking, rapportering og undersøkelse. For disse tiltak vektlegger FNs Barnekomité at risikofaktorer for enkeltbarn eller barn som gruppe først og fremst må identifiseres av dem som kommer i kontakt med barn. Nødvendigheten av at disse har nødvendig kunnskap for slik identifisering fremheves, samt at bekymringer formidles til rette instans for eventuell undersøkelse. En undersøkelse skal ifølge FNs Barnekomité omfatte vurderinger av barnets og omsorgsgivernes/familiens behov, dernest henvisning til et adekvat tjenestetilbud. (2011 s. 21).

\section{Barnets beste som grunnleggende hensyn i saker om beskyttelse av barn}

Barnekonvensjonens art. 3 slår fast at «Ved alle handlinger som berører barn ..[...].. skal barnets beste være et grunnleggende hensyn». Etter Children Act sec 1 skal barnets velferd (childs welfare) tillegges avgjørende vekt. Den norske Grunnlovens $§ 104$ bygger på konvensjonsbestemmelsen, og fastslår i sitt 2. ledd at barnets beste skal være et grunnleggende hensyn ved handlinger og avgjørelser som angår barn. Ordlyden «et» grunnleggende hensyn innebærer ikke at hensynet skal være «det» avgjørende, noe BK art. 9 nr. 2 legger til grunn ved avgjørelser om adskillelse av barn og foreldre. Her kreves at «slik atskillelse er nødvendig av hensyn til barnets beste», en ordlyd som presiserer at hensynet til barnets beste skal være det avgjørende. At barnets beste skal tillegges avgjørende vekt fremgår også av barnevernloven § 4-1 (2). Der ulike hensyn må veies mot hverandre, for 
eksempel hensynet til barnet, til foreldrene eller til samfunnet, skal barnets beste være tungtveiende. Andre prinsipper som underbygger barnets beste er prinsipper om

\section{lovmessighet, forholdsmessighet og bevaring av familieforhold, i tillegg til barnets rett til medvirkning.}

Lovmessighet som grunnlag for myndigheters inngrep i et barns privat- og familieliv fremgår av BK art. 16, jfr. også EMK art. 8. I England er myndighetene gjennom deres ukodifiserte grunnlov pålagt å følge den ratifiserte barnekonvensjonen, og i Norge fremgår det av Grunnloven $\S 113$ at «Myndighetenes inngrep overfor den enkelte må ha grunnlag i lov». I Children Act og barnevernloven fremgår legalitetsprinsippet implisitt ved at lovene stiller vilkår for de ulike inngrepsformer. Forholdsmessighet innebærer at myndigheter skal søke å velge de mildeste inngrep og handlinger som er formålstjenlige og forsvarlige, og EMK art. 8 og BK art. 9 nr. 2 illustrerer dette gjennom ordlyden om at tiltak skal være «nødvendig» for å ivareta et eller flere av de formål som fremgår av bestemmelsen. I Children Act fremgår prinsippet i ulike bestemmelser, herunder sec 47(4) om at barneverntjenesten i en undersøkelsessak:

"shall (with a view to enabling them to determine what action, if any, to take with respect to him) take such steps as are reasonably practicable..[..]..to obtain access to him..[..].. unless they are satisfied that they already have sufficient information with respect to him."

I barnevernloven fremgår prinsippet eksempelvis ved at undersøkelser ikke skal gjøres «mer omfattende enn formålet tilsier» $(\S 4-3(2))$, samt at tjenester etter barnevernloven skal være forsvarlige (§ 1-4).

Barnets rett til å bevare sitt familieforhold uten ulovlig innblanding fremgår av BKs art. 8 og 9; adskillelse mellom barn og foreldre skal ikke skje med mindre «slik adskillelse er nødvendig av hensynet til barnets beste». Både i England og Norge synliggjøres dette gjennom parental responsibility/foreldreansvaret (Children Act sec 3 (1), Barneloven § 30)). I begge landenes lovgivning omfatter foreldreansvaret omsorg, ansvar, rettigheter og plikter overfor sitt barn, herunder til å ta avgjørelser for sitt barn (Kane 2006). Children Act pålegger de lokale barnevernmyndigheter, så langt det er i tråd med deres plikt til å sikre barns velferd,

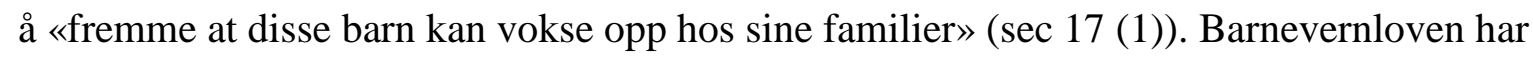
ikke tilsvarende eksplisitte bestemmelse, men av lovens forarbeider (NOU 2012:5) kap. 2.2.1 fremgår at «I tråd med samfunnsutviklingen for $\emptyset$ vrig er det fortsatt vektige momenter som 
tilsier at barn bør vokse opp i sin familie, men dette kan fravikes i tilfeller der det er til barnets beste. Utvalget støtter føringen om at prinsippet om barnets beste er overordnet».

Barnets rett til å hørt i sin egen sak følger av BKs art. 12, barnet skal «særlig gis anledning til å bli hørt i enhver rettslig og administrativ saksbehandling som angår barnet». Barnets synspunkter skal gis «behørig vekt i samsvar med dets alder og modenhet». Ifølge FNs Barnekomités generelle kommentarer nr. 13 (2011 s. 8) innebærer dette at «barnet har rettigheter som gir det innflytelse over sitt eget liv, og ikke bare rettigheter på grunn av sin sårbarhet (retten til beskyttelse) eller sin avhengighet av voksne (retten til omsorg)». Children act sec 47(5) (A) pålegger myndighetene å sikre at barnets meninger i en sak som gjelder han/henne kommer fram og blir vektlagt i forhold til barnets alder og forståelse. I rundskrivet «Working Together to Safeguard Children» (2015) pkt 38 fremgår at i alle undersøkelsessaker skal barnets syn fremgå, i tillegg til foreldrenes. For barn i Norge fremgår retten til å bli hørt av ulike lover, og er tilpasset det enkelte barnets alder og modenhet. Av barneloven $\S 31$ fremgår at barnet har rett til å uttale seg i personlige forhold, mens barnevernloven §§ 4-1 (2) og 6-3 pålegger barneverntjenesten å muliggjøre barnets medvirkning i egen sak, tilrettelegge for samtaler med barnet, og å gi barnet informasjon og anledning til å uttale seg før det treffes en avgjørelse i en barnevernssak.

\section{Barnets rett til beskyttelse mot vold og omsorgssvikt avhenger av at bekymringsverdige forhold rundt barnet blir identifisert, videreformidlet og undersøkt.}

\section{Bruk av fysisk avstraffelse i oppdragelsesøyemed}

Hvorvidt barnets rett til beskyttelse mot overgrep omfatter rett til fravær av fysisk avstraffelse, er et forhold som fremgår ulikt av de to landenes lover.

I England har foreldre adgang til å utøve «reasonable punishment» (rimelig avstraffelse), så lenge det ikke medfører fysisk skade av et slikt omfang at det ville vært straffbart etter straffelovgivningen (The Children Act England and Wales $2004 \mathrm{sec} 58$ ). Nevnte bestemmelse presiserer i pkt (3) at avstraffelse som medfører kroppskrenkelse faller utenfor begrepet «reasonable punishment». 
I Norge forbyr barneloven $\S 30$ all voldsutøvelse overfor barn, også «når valden brukast som ledd i oppsedinga av barnet». Laveste terskel for vold etter straffeloven (2005) § $271 \mathrm{er}$ kroppskrenkelse, som ifølge forarbeidene samlet sett dreier seg om en kraftanstrengelse mot en persons kropp, av en viss styrke slik at den føles ubehagelig. Det kan dreie seg om slag, spark, lugging, kloring, harde grep, kasting og hard holding, dog uten spesifikt krav om at handlingen(e) har påført personen skade eller smerte (Ot.prp. nr 22, (2008-2009).

Forbudet mot vold i oppdragelsen har vært omdiskutert også i Norge. I 2005 uttalte Høyesterett (Rt 2005 s.1567) at forsiktige klaps som ledd i barneoppdragelse ikke antas å være straffbar legemsfornærmelse. ${ }^{\text {iv }}$ Vurderingene som kommer til syne i dommen kan sies å ligge nærmere ordlyden i Children Act 58 enn ordlyden i barneloven $§ 30$; nemlig at ikke alle ubehagelige kraftanstrengelser mot et barns kropp er å anse som vold, dersom handlingen ikke rammes av straffelovgivningen som kroppskrenkelse.

Dette åpner for spørsmålet om barnets rett til beskyttelse mot vold gjelder alle former for vold, eller kun mot de former som medfører skade, smerte eller ubehag, og derfor rammes av straffelovgivning. I følge BK art. 37(a) skal ikke barn utsettes for «tortur eller annen grusom, umenneskelig eller nedverdigende behandling». FNs Barnekomité har i sin generelle kommentar nr. 13 (2011, pkt 24) definert fysisk avstraffelse som «all straff der det brukes fysisk makt, og der hensikten er å volde en viss grad av smerte eller ubehag, uansett hvor lite det er snakk om», og peker på «klaps»som en slik form. Barnet har etter BK art. 19 rett til beskyttelse mot alle former for vold, uten krav om at den aktuelle vold må medføre skade eller være straffbar. FNs Barnekomité poengterer i sine generelle kommentar (2011 s. 8) at alle former for voldsbruk, uansett hvor milde, er uakseptable, og at der ikke finnes rom for noen former for legalisert vold. Ut fra dette er det grunn til å hevde at ordlyden i barnelovens $\S 30$ samt barnekonvensjonens art. 19 signaliserer nulltoleranse for fysiske avstraffelsesformer og at også «forsiktige klaps» som beskrevet i RT 2005 s. 1567 omfattes av voldsbruk som barnet har menneskerettslig krav på beskyttelse mot.

\section{Terskler for å melde fra til barnevernmyndighet om bekymringer for et barn.}

Barnets rett til beskyttelse kan også fremmes eller hemmes av hvordan nasjonal lovgivning regulerer yrkesutøveres eventuelle plikt til å videreformidle bekymringer om overgrep eller omsorgssvikt overfor barnet til barnevernmyndighetene. Beskyttelsestiltak for å beskytte barnet bør etter BK art. 19(2) omfatte effektive prosedyrer for påpeking, rapportering og 
undersøkelse, og ansvaret for å beskytte barn mot overgrep og omsorgssvikt påligger etter artikkelens ordlyd alle myndigheter som arbeider med og for barn. Dermed omfattes blant andre barnehager, skoler, helse-, omsorgs- og sosiale tjenester og barneverntjenester.

De to lands lovregulering om hvem som skal/bør videreformidle opplysninger om barn som vurderes å være i risiko er ulike. De forskjeller jeg her vil belyse er at:

- terskler for melding/henvisning fremgår av rundskriv i England og lov i Norge,

- melding til barneverntjenesten er en sterk oppfordring i England, og en plikt for utpekte yrkesutøvere i Norge,

- meldingsoppfordringen i England gjelder bekymringer barns velferd generelt, mens meldeplikten i Norge omfatter de alvorligste bekymringer for omsorgssvikt og atferdsproblemer, samt

- meldingsoppfordringen i England retter seg til en ubestemt krets av personer mens meldeplikten i Norge påligger utpekte yrkesutøvere.

Children Act har ingen eksplisitt lovbestemmelse som pålegger noen å videreformidle bekymringsmeldinger til barneverntjenesten. I rundskrivet «Working Together» (2015 pkt 19) fremgår: «Anyone who has concerns about a child's welfare should make a referral to a local authoritys children's social care», fritt oversatt: «Alle som er bekymret for et barns velferd bør inngi henvisning til kommunens barneverntjeneste». Denne rundskrivsbestemmelsen har flere klare forskjeller fra de norske bestemmelser om uanmodet meldeplikt. For det første brukes verbet «should», som språklig tilsvarer et forsterket «bør». Dette er i motsetning til presensformen «shall» som innebærer en plikt. Ut fra vanlig språkforståelse innebærer den engelske rundskrivsbestemmelsen en sterk oppfordring til å sende henvisning om bekymringer, men ingen lovpålagt plikt tilsvarende norsk rett. For det andre omfatter den engelske oppfordringen bekymringer rundt et barns velferd generelt, mens den norske meldeplikten omfatter de alvorligste bekymringer for barn, herunder bekymringer for alvorlig omsorgssvikt og alvorlige atferdsvansker. For det tredje og siste er ikke bestemmelsen tydelig på hvem som gis denne oppfordringen, da ordet «anyone» betyr «alle». Brayne et al. (2014 s. $235)$ poengterer at «The protection of children is dependent upon everyone who works with children or is in contact with them being able to recognize indicators that a child's welfare or safety may be at risk». Skal barn beskyttes, må risiko observeres og identifiseres av både profesjonelle og private som har med barnet å gjøre. 
I Norge har yrkesutøvere i ulike tjenester for barn en lovpålagt plikt til uanmodet å gi opplysninger til barneverntjenesten (meldeplikt) når de opplever alvorlige bekymringer for et barn jfr barnevernloven § 6-4(2) og ulike særlover. ${ }^{v}$ Meldeplikten inntrer ved bekymringer for at et barn lever under ulike former for alvorlig omsorgssvikt samt andre alvorlige forhold og risikofaktorer. Bekymringer som skulle tilsi at barnet har behov for et hjelpetiltak utløser ikke slik meldeplikt, slike opplysninger omfattes av yrkesutøvernes taushetsplikt. ${ }^{\mathrm{vi}}$ Eventuell opplysning til barneverntjenesten må i slike tilfeller baseres på samtykke.

Hvordan kan barnets rett til beskyttelse påvirkes av hvorvidt bekymringer rundt barnet skal eller $\underline{b ø r}$ formidles fra fagpersoner til ansvarlige myndigheter? FNs Barnekomité uttaler i sin generelle kommentar nr. 13 (2011 s 21) at: «I ethvert land bør det som et minimum kreves av fagpersoner som arbeider direkte med barn, at de rapporterer om voldelige episoder og mistanke om eller fare for vold». Komiteen bruker ordlyden «bør», altså en sterk oppfordring og ikke en plikt, slik ordlyden i Children Act også er. Sett i lys av barnets rett til beskyttelse mot overgrep og omsorgssvikt kan barnets rett, på den ene siden, være bedre ivaretatt gjennom Norges lovpålagte meldeplikt enn ved Englands sterke oppfordring til å henvise, i et rundskriv. På den andre siden kan en tenke at barnets beskyttelse sikres bedre gjennom Englands bestemmelser om at henvisningsoppfordringen adresserer bekymringer rundt et barns velferd generelt, enn gjennom Norges meldeplikt i barnevernloven $§ 6-4$ som mer eksplisitt viser til situasjoner og bekymringer som kan dekkes av beskrivelsene i fem ulike tvangsparagrafer i barnevernloven:

«..[..]..at et barn blir mishandlet i hjemmet eller det foreligger andre former for alvorlig omsorgssvikt, jf. §§ 4-10, 4-11 og 4-12, når et barn har vist vedvarende alvorlige atferdsvansker, jf. § 4-24, eller når det er grunn til å tro at det er fare for utnyttelse av et barn til menneskehandel, jf. § 4-29».

Implisitt innebærer bestemmelsen at meldeplikt inntrer der for eksempel en lærer eller helsesøster er bekymret for et barn, og der bekymringen i sin art og sitt innhold tilsier at vilkårene for eksempelvis omsorgsovertakelse eller institusjonsplassering er til stede. Ordlyden i seg selv fordrer at alle som arbeider med barn må ha tilstrekkelige kunnskaper om de ulike tvangstiltak og deres vilkår, samt hvilke bekymringsverdige forhold som anses å oppfylle vilkårene. Disse kunnskapene må ligge til grunn for at yrkesutøverne skal vite når de har taushetsplikt og når deres plikt inntrer til å melde fra til barneverntjenesten om ellers taushetsbelagte opplysninger om et barn. Det kan diskuteres om ordlyden «andre former for alvorlig omsorgssvikt», etterfulgt av en rekke paragrafhenvisninger, burde vært erstattet med 
en tekstliggjøring av hvilke forhold eller bekymringer som skal medføre meldeplikt. Med tanke på BK art. 19 sine krav om «alle egnede lovmessige» tiltak for å beskytte barnet, samt at beskyttelsestiltak bør omfatte effektive prosedyrer for rapportering, er det betimelig å rette søkelys mot ordlyden i meldepliktbestemmelsen i barnevernloven $\S 6-4$. For at barn mer effektivt skal kunne beskyttes mot overgrep og omsorgssvikt gjennom at ulike yrkesutøvere faktisk melder fra om alvorlige bekymringer, kan en hevde at lovbestemmelser om meldingsinngivelse bør være så konkrete som mulig.

\section{Terskler for igangsettelse av barnevernsundersøkelse}

I følge BK art. 19 bør beskyttelsestiltak omfatte «effektive prosedyrer for unders $\varnothing$ kelse» i forhold til de former for overgrep og omsorgssvikt som barnet skal beskyttes mot. Plikten til å gjennomgå innkomne bekymringsmeldinger og å igangsette undersøkelse der lovens vilkår tilsier det, er relativt lik i England og Norge (Kane 2006). De to landenes lover har likevel ulike vilkår for igangsettelse og for gjennomføring av undersøkelse, hvorav terskelen er høyere i England enn i Norge.

Etter Children Act sec 47 (1) inntrer undersøkelsesplikt dersom det er rimelig grunn til å anta at et barn «suffer significant harm» (lider betydelig skade). I følge barnevernloven $§ 4-3$ skal undersøkelse igangsettes dersom det er «rimelig grunn til å anta at det foreligger forhold som kan gi grunnlag for tiltak etter dette kapitlet». Det mildeste tiltaket i barnevernloven kapittel 4 er det samtykkebaserte hjelpetiltak, hvor grunnvilkåret for å iverksette er at barnet har «særlig behov» for det (§ 4-4(2)). Kriteriet om betydelig skade er i sin ordlyd sterkere enn kriteriet om «særlig behov», dermed er terskelen høyere for å igangsette en undersøkelse i England enn i Norge.

Sett i lys av barnets rett til beskyttelse i Norge kan det diskuteres hvor høy eller lav terskelen for igangsettelse av en barnevernunders $\emptyset$ kelse bør være. En barnevernunders $\emptyset$ kelse er et omfattende inngrep i barnets privat- og familieliv, som barnet og familien ikke kan motsette seg (barnevernloven $\S 4-3,3$. ledd). Terskelen for igangsettelse bør derfor stå i forhold til hvilke tjenester og tiltak som vurderes som aktuelle ut fra den innmeldte bekymringen. Alvorlige bekymringer tilsier en grundig barnevernunders $\emptyset$ kelse for å beskytte barnet og for å kunne treffe en forsvarlig og lovmessig avgjørelse om tiltak. 
Det kan også diskuteres om terskelen for å igangsette en barnevernunders $\varnothing$ kelse burde vært høyere der bekymringene omhandler forhold som også kan avhjelpes av andre velferdstjenester. Noen bekymringsmeldinger resulterer i samtykkebaserte hjelpetiltak, hvor innholdet i tiltakene i ulik grad tilsvarer innholdet i tjenester som forvaltes av andre etater enn barneverntjenesten. Av de 82.736 barneverntiltakene som er registrert i 2014, fremgår det at om lag en tredel av disse (ca. 25.500) har likhetstrekk med tjenester etter helse- og omsorgstjenesteloven 2011 (støttekontakt, hjemkonsulent/miljøarbeider, fritidsaktiviteter, psykisk helsetjeneste, ruskontroll), barnehageloven 2005 (barnehageplass), opplæringsloven 1998 (SFO/aktivitetsskole) sosialtjenesteloven 2009 ( $\varnothing$ konomisk bistand, utdanning/arbeid, bolig). ${ }^{\text {vii }}$ I tillegg var det rapportert inn 8.263 tiltak om «samarbeid med andre tjenester». Dette illustrerer at andre etaters tjenester er tydelig representert i de registrerte barneverntiltakene. Det kan derfor tenkes at enkelte barns særlige behov for tiltak kunne blitt forsvarlig ivaretatt gjennom andre tjenester enn barneverntiltak, herunder kommunale omsorgstjenester, ulike helsetjenester, sosiale tjenester og spesialpedagogiske tiltak i skolen. Nevnte velferdstjenester kan oppleves som mindre inngripende og stigmatiserende for barnet og foreldrene enn et barneverntiltak og derfor lettere å ta imot. I slike saker kan det derfor tenkes barnets rett til beskyttelse ivaretas forsvarlig ved at foreldrene får informasjon og eventuelt bistand til selv å søke om eksempelvis barnehageplass eller støttetiltak i skolen i stedet for at det opprettes barnevernssak.

Bekymringsmeldinger til barneverntjenesten kan også resultere i henleggelse før, under eller etter unders $\varnothing$ kelse, og noen av disse meldinger og unders $\varnothing$ kelsesprosesser kan ha medført uforholdsmessig store inngrep i barnets og familiens privatliv.

\section{Fokusområder og fremgangsmåter i barnevernsundersøkelse}

Et barns rett til beskyttelse påvirkes av hvilke fokusområder og fremgangsmåter de ansvarlige myndigheter forholder seg til ved undersøkelser, og disse områdene er også ulikt beskrevet i de to landenes lovgivning.

Children Act sec 47 pålegger kommunen å ta de steg som er rimelig gjennomførbare for å oppnå/sikre tilgang til barnet, for å fastslå hvilke eventuelle handlinger som skal iverksettes. Lovbestemmelsen suppleres av et rammeverk for undersøkelser i rundskrivet «Working Together to Safeguard Children» (2015 pkt 37) gjennom følgende modell: 


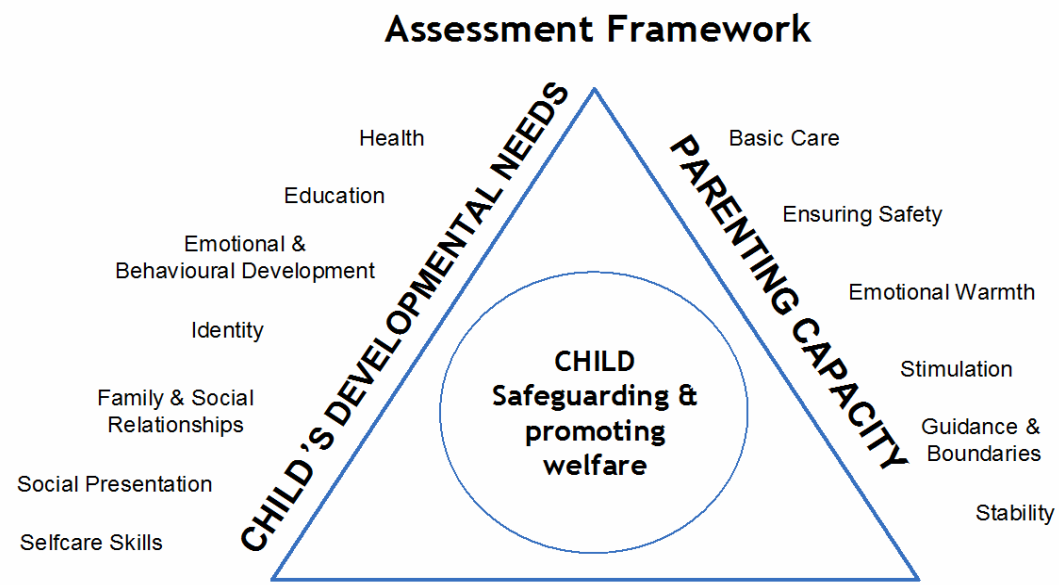

FAMILY \& ENVIRONMENTAL FACTORS

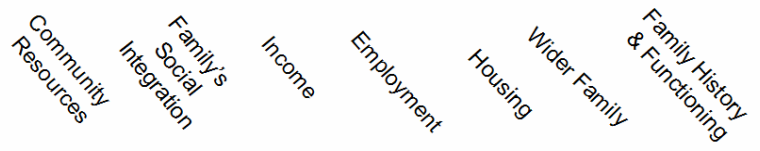

(fig1: The Assessment Framework. Department of Health 2015)

En undersøkelse skal etter denne modellen omfatte både barnets utviklingsmessige behov, foreldrenes omsorgskompetanse i forhold til barnets behov, samt $\varnothing$ vrige familie- og miljøfaktorer. Innenfor hvert av disse tre hovedområdene spesifiseres 20 ulike områder som skal vurderes. Undersøkelsens formål er å samle relevant informasjon om et barn og dets familie, dernest skal det vurderes og tas stilling til hvorvidt barnet har særlige behov og/eller utsettes for risiko eller skade. I tillegg skal de behov som avdekkes imøtekommes for å sikre barnet (Working Together 2015 pkt 29).

Etter barnevernloven $§ 4-3$ er det «forholdet» som kan gi grunnlag for et barneverntiltak som skal undersøkes, altså hvorvidt barnet minimum har et særlig behov for et hjelpetiltak, eventuelt for mer inngripende tiltak. Undersøkelsen skal gjennomføres med minst mulig skade og omfang, og med hensyn til familielivet og barnets beste. Unders $\varnothing$ kelsen skal videre gjennomføres forsvarlig (bvl § 1-4), og forarbeidene til barnevernloven (ot.prp 44-91/92) beskriver at valg av undersøkelsesmåte må overlates til barneverntjenesten. Barnevernansatte må derfor anvende faglig skjønn for å vurdere hva som skal undersøkes, av hvilken grunn, hvordan man skal undersøke det, og hvordan det som avdekkes i undersøkelsen skal vektlegges (Kane 2006). I Rutinehåndbok for Barneverntjenesten i kommunene (2006) pkt 
4.4.2 (2) (e), fremgår at undersøkelsen skal «stå i forhold til meldingens innhold» og at barnet skal «vurderes i kontekst». Videre beskrives i samme punkt at «innhenting av relevant informasjon fra viktige arenaer i barnets liv, for eksempel skole, barnehage, hjemmet og fritidsaktiviteter, vil kunne være nyttig i undersøkelsen». Rutinehåndbokas pkt 4.6 presenterer også noen momentlister for innhenting av informasjon fra skole, barnehage og helsetjenester.

Hvorvidt barnets rett til beskyttelse fremmes bedre gjennom skjønnsmessige vurderinger eller en mer detaljert sjekkliste kan diskuteres. Samsonsen og Willumsen (2014) intervjuet sosialarbeidere i Norge og England om deres erfaringer med barnevernunders $\emptyset$ kelser. Undersøkelsen viser at sosialarbeidere i Norge fremhevet sitt faglige skjønn, men ønsker et bedre strukturert rammeverk for sin skjønnsutøvelse. I England fremhevet sosialarbeiderne sitt rammeverk «Assessment Framework» (fig 1), men ønsket også å bli vist mer tillit med hensyn til sin faglige skjønnsutøvelse. Dette illustrerer et behov både for et tydelig rammeverk for hvilke områder som skal undersøkes rundt det enkelte barn, og for adgang til å utøve individuelt faglig skjønn innenfor de gitte rammene. «Assessment Framework» med sine 20 spesifiserte områder for hva en barnevernundersøkelse skal omfatte, kan sies å fremme hensynet til barns rett til likhet for loven ${ }^{\text {viii }}$ samt hensynet til lovmessighet. Samtidig er områdene skjønnsmessige og individbaserte, noe som fremmer hensynene til forsvarlighet, forholdsmessighet og barnets beste. Ut fra dette er det tenkelig at et lignende rammeverk i forskrift eller rundskriv tilhørende barnevernloven kunne bidratt til at barnets helhetlige oppvekstsituasjon ble bedre kartlagt, og barnets rett til beskyttelse ble bedre ivaretatt.

\section{Barnets beste i saker om beskyttelse av barn - i lovenes ordlyd og utforming}

Som nevnt under del 2.3 skal prinsippet om barnets beste tillegges avgjørende vekt i saker som omhandler beskyttelse av barn i Norge og England. Likevel har de to landenes lover forskjellig utforming med hensyn til hvor i loven prinsippet er plassert, hvilke saker prinsippet skal gjelde i, samt hvilke faktorer som skal inngå i en barnets-beste-vurdering.

I barnekonvensjonen og Children Act fremkommer prinsippet som de første bestemmelser (BK art 3, Children Act sec 1), mens det i barnevernloven først fremkommer i lovens fjerde kapittel, § 4-1. I barnekonvensjonen gjelder prinsippet alle handlinger som angår barn, og i Children Act sec 1 gjelder det alle spørsmål rundt et barns oppvekst. I barnevernloven er prinsippet plassert under kapitteloverskriften "særlige tiltak" (kap 4) $)^{\text {ix }}$, og er knyttet til å "finne tiltak som er til beste for barnet". I begge eksempler ligger den engelske barnevernlovgivningen nærmere barnekonvensjonen enn den norske. På den annen side 
påligger prinsippet spesifikt domstolene det etter Children Act sec 1, mens barnekonvensjonen knytter prinsippet til "alle handlinger som angår barn”, tilsvarende den norske Grunnloven $§ 104$. Et barns rett til beskyttelse mot overgrep og omsorgssvikt innebærer i den enkelte sak kompleks skjønnsutøvelse med tanke på både kartlegging, vurderinger og beslutninger, og i alle ledd skal barnets beste være det grunnleggende hensyn. Ut fra hensynet til lovteknisk enhetlighet burde derfor prinsippet om barnets beste kunne derfor vært plassert først i loven, eksempelvis i tilknytning til § 1-4 om kravet til forsvarlighet.

Når det gjelder innholdet i en barnets beste-vurdering kan en trekke fram at Children Act sec 1 presenterer en «check-list» over faktorer som skal vurderes. Listen omfatter faktorer som barnets $\emptyset$ nsker, behov, sannsynlige effekter av endringer, alder/kjønn, hvilke former for overlast han/hun lider eller risikerer å lide, foreldrenes omsorgskompetanse og hvilke avgjørelsesformer retten disponerer. Barnevernloven har ikke en tilsvarende detaljert oversikt over hva en vurdering av barnets beste i enkeltsaker skal omfatte. Av lovens § 4-1 fremgår at barnets beste omfatter stabilitet, kontinuitet og medvirkning, altså en mer skjønnsmessig tilnærming. Med tanke på BK art. 19 om barnets rett til beskyttelse mot alle former for overgrep og omsorgssvikt, samt Grunnlovens art. 104 om at barn har krav på respekt for sitt menneskeverd og rett til vern om sin personlige integritet, synes det relevant å påpeke at vurderingsområdene i en barnets beste-vurdering kunne vært mer detaljert beskrevet i barnevernloven.

\section{Oppsummering og avsluttende betraktninger}

England og Norge er bundet av Barnekonvensjonen og dens bestemmelse om barnets rett til beskyttelse, og har inkorporert grunnleggende prinsipper om lovmessighet, forholdsmessighet og barnets beste i sin barnevernlovgivning. Lovene har noen forskjeller med hensyn til innhold, utforming og terskler; hvilke ulike konsekvenser kan de påpekte forskjeller ha for barnets menneskerettslige krav på beskyttelse?

Omfatter barnets beskyttelsesrett en rett til frihet fra fysisk avstraffelse i alle former? I England er en rimelig fysisk avstraffelse i oppdragelsesøyemed tillatt. I Norge er det forbud mot bruk av vold, likevel har Høyesterett uttalt at forsiktige klaps ikke er omfattet av forbudet. Ut fra FNs Barnekomités uttalelser om det ikke finnes rom for noen former for 
legalisert vold, må konklusjonen være at barnets rett til beskyttelse innebærer en nulltoleranse for voldsbruk.

Barnets rett til beskyttelse mot overgrep og omsorgssvikt avhenger av at de ansvarlige yrkesutøvere både er i stand til å identifisere mulig risiko hos et barn og til å agere lovmessig og forsvarlig i forhold til dette. Når fagpersoner observerer bekymringsverdige forhold ved et barn, må opplysningene videreformidles til ansvarlig barnevernmyndighet for at barnet skal kunne beskyttes gjennom at forholdene unders $\varnothing$ kes og eventuelle tiltak kan iverksettes. Bare Norge har slik lovpålagt meldeplikt, og det er derfor nærliggende å konkludere med at den norske meldeplikten ivaretar denne beskyttelsesrettigheten i størst grad.

Begge land har lovgivning som regulerer barnevernmyndighetenes undersøkelser ved bekymringer rundt barnet, men terskelen for igangsetting av undersøkelse i en barnevernssak er høyere i England enn i Norge. Ivaretas barnets beskyttelsesrett bedre når terskelen er antakelser om at barnet har særlige behov eller antakelser om at barnet lider betydelig skade? Ut fra begrunnelsen om at terskelen for igangsettelse av undersøkelse bør stå i forhold til hvilke tjenester og tiltak som vurderes som aktuelle ut fra innholdet i bekymringsmeldingen har jeg kommet til en delt konklusjon. Alvorlige bekymringer tilsier en lav inngrepsterskel mens terskelen bør være høyere i saker hvor de bekymringsmessige forhold også kan avhjelpes av andre velferdstjenester enn barneverntiltak.

Mens Englands «Assessment Framework» skal sikre hvilke områder i barnets oppvekstvilkår som skal undersøkes, overlates disse områdene mer til barneverntjenestens skjønn i Norge. Ut fra at hensynet til barnets beskyttelsesrett fordrer at barnevernunders $\emptyset$ kelser er helhetlige, grundige og individuelle, kan det hevdes at unders $\varnothing$ kelse bør baseres på tydelig beskrevne fokusområder, hvor det også er plass for nødvendig individuelt og faglig skjønn.

Barnets rett til beskyttelse innebærer også at alle handlinger og avgjørelser som angår barnet skal gjøres ut fra hensynet til Barnets Beste. Med den begrunnelsen har jeg problematisert at den norske barnevernloven presenterer Barnets Beste først i lovens kapittel 4, mens den fremgår av Children Acts første bestemmelse. I tillegg hevder jeg at barnets beskyttelsesrett fremmes av at de vurderingsområder som skal inngå i en barnets beste-vurdering beskrives i barnevernlovgivningen - slik det gjøres i Children Act sec 1 og ikke i barnevernloven § 4-1. Barnets rett til beskyttelse gjennom lovgivning i de ratifiserende land fremgår i stor grad av skjønnsmessige bestemmelser i ulike rettskilder som konvensjoner, lover og offentlige 
dokumenter. De forskjeller jeg her har pekt på mellom norsk og engelsk rett stammer i stor grad fra slike skjønnsmessige bestemmelser, eksempelvis «barnets beste/childs welfare, «bekymringer/concerns», «reasonable punishment» og «særlige behov/in need».

Yrkesutøvere som arbeider med barn trenger gode fagkunnskaper for å kunne treffe avgjørelser som ivaretar barns behov. I tillegg trengs til en viss grad juridiske kunnskaper for å kunne fortolke de ulike lovers formål og vilkår og for å kunne vurdere hvordan disse skal anvendes i det enkelte barns situasjon. Forsvarlig skjønnsutøvelse krever at yrkesutøvernes faktiske og faglige vurderinger og beslutninger ligge innenfor rammene av de gjeldende lover. Skjønnsmessige lovbestemmelser må fortolkes i tråd med bestemmelsenes ordlyd og formål, og anvendes korrekt ut fra hver saks individuelle forhold (Kane 2015). Barnevernets skjønnsutøvelse skal ta utgangspunkt i det enkelte barns beste, noe som også innebærer helt individuelle vurderinger. Samtidig skal vurderingene skje innenfor rammer av lov for å ivareta prinsipper om legalitet og likebehandling. Selv om barnevern er et klart lovregulert område, kan barnevernansattes skjønnsutøvelse utfordres av ulike grunner. Križ og Skivenes peker på at lovgivning kan være «quite vague and contradictory» (2014 s. 2), og eksemplifiserer med at prinsippet om å bevare familier intakt kan stride mot barnets beste. I tillegg vil barnevernets skjønnsutøvelse påvirkes av ulik fagbakgrunn, kompetanse og erfaring hos de ansatte. En kan derfor hevde at barnets menneskerettslige krav på beskyttelse kan fremmes av nasjonal lovgivning som både er tydelig på hvilke beslutninger som kan fattes på hvilke vilkår samt med hvilke krav til saksbehandling, og som gir tilstrekkelig skjønnsrom til at beslutningene tar tilstrekkelig hensyn til det individuelle barns beste. 


\footnotetext{
${ }^{\mathrm{i}}$ http://www.ucl.ac.uk/constitution-unit/whatis/uk-constitution, sitert 091215.

ii http://www.nspcc.org.uk/preventing-abuse/child-protection-system/england/statistics/, http://www.ssb.no/a/barnogunge/2015/tabeller/barnevern/barnev0200.html og http://www.ssb.no/sok?hovedemner=Befolkning\&innholdstype=nokkeltallsside \&sok=barn+og+unge (alle sitert 091215)

iii http://www.nspcc.org.uk/preventing-abuse/child-protection-system/england/statistics/, http://www.ssb.no/a/barnogunge/2015/tabeller/barnevern/barnev0200.html og http://www.ssb.no/sok?hovedemner=Befolkning\&innholdstype=nokkeltallsside \&sok=barn+og+unge (alle sitert 091215)

iv Jfr straffeloven 22.mai $1902 \mathrm{nr} 10$ § 228, opphevet ved ikrafttredelse av straffeloven 28. mai $2005 \mathrm{nr}$ 28, ikraft fra 1. oktober 2015.

${ }^{\mathrm{v}}$ Se for eksempel sosialtjenesteloven 18.des 2009 § 45, helsepersonelloven 2. juli 1999 § 33, barnehageloven 17. jun 2005 § 22, opplæringsloven 17. jul 1998 § 15-3 og familievernkontorloven 19.jun 1997 § 10.

${ }^{v i}$ Forvaltningsloven 1967 § 13, helsepersonelloven 1999 § 21, barnevernloven 1992 § 6-7, sosialtjenesteloven $2009 \S 44$.

vii http://www.ssb.no/a/barnogunge/2015/tabeller/barnevern/barnev0200.html. (sitert 091215)

viii Jfr FNs verdenserklæring om menneskerettigheter 10. des 1948 art 7, Grunnloven $§ 98$

${ }^{i x}$ Begrepet «barnets beste» fremgår også av barnevernloven § 1-3 i.f. ang. begrunnelser for opphør/avslag av barneverntiltak, med en henvisning til lovens § 4-1.
}

\section{Referanser (5)}

Aall J (2011). Rettsstat og menneskerettigheter. 3. utg. Bergen: Fagbokforlaget.

Aasen, H.R. (2000). Pasientens rett til selvbestemmelse ved medisinsk behandling. Bergen: Fagbokforlaget.

Barne- og likestillingsdepartementet (2006). Rutinehåndbok for barneverntjenesten $\boldsymbol{i}$ kommunene. Q-1101.

Brayne H., Carr H. og Goosey D. (2014). «Law for Social Workers». 13th ed. Oxford: Oxford University Press.

Eckhoff T. (1963). Legalitetsprinsippet. Tidsskrift for rettsvitenskap,1. Oslo: Universitetsforlaget.

FNs Barnekomités Generell kommentar nr 8 (2006). Barnets rett til beskyttelse mot fysisk avstraffelse og andre grusomme eller nedverdigende former for straff (bl.a. artikkel 19, artikkel $28 \mathrm{nr} .2 \mathrm{og}$ artikkel 37).

FNs Barnekomités Generell kommentar nr 13 (2011). Barnets rett til frihet fra alle former for vold.

FNs Barnekomités Generell kommentar nr 14 (2013). Om barnets rett til at hans eller hennes beste skal være et grunnleggende hensyn (art. 3, para 1). 
Hennum R. (2012). Retten til beskyttelse mot vold, overgrep og utnyttelse. I Høstmælingen N, Kjørholt ES, Sandberg K (red). 2012. BK. Barns rettigheter i Norge. 2. utg. Oslo:

Universitetsforlaget.

H.M Government. (2015). Working Together to Safeguard Children. A guide to interagency working to safeguard and promote the welfare of children. London: H.M Government.

Kane A. (2006). Barnevernarbeid i Norge og England. En fremstilling og sammenligning av de juridiske rammer rundt intervensjoner i familier ved mistanke om omsorgssvikt.

Høgskolen i Harstad skriftserie 3.

Kane A. (2015). Greit at det finnes lover, men det må da vel være lov å bruke skjønn». I Stat og Styring 1. Oslo: Universitetsforlaget.

Kjønstad A og Syse A. (2012). Velferdsrett I. Grunnleggende rettigheter, rettssikkerhet og tvang. 5. utg. Oslo: Gyldendal Akademisk.

Križ , K. og Skivenes, M. (2014). Street-level policy aims of child welfare workers in England, Norway and the United States: an exploratory study. Children and Youth Services Review 40.

Lilleholt K, Mestad O og Selmer K (2009): Rettssystemet. I Lilleholt K (red): Knophs oversikt over Norges rett. 13. utg. Oslo: Universitetsforlaget.

Norsk Retstidend 2005 s 1067.

Ot.prp 44 (1991-1992). Om lov om barneverntjenester.

Ot.prp. nr. 22 (2008-2009). Om lov om endringer i straffeloven.

Samsonsen V og Willumsen E (2014): Assessment in Child Protection. Social workers' voices in England and Norway. Journal of Comparative Social Work 2014/1. University of Nordland, Bodø.

Samsonsen V og Willumsen E (2015): Narratives from parents in England and Norway; Power and emotions in child protection assessments. Journal of Comparative Social Work 2015/1. University of Nordland, Bodø.

Skivenes, M. (2011). Norway - Toward a child centric perspecitve. I Gilbert N., Parton N. og Skivenes, M. (red). Child Protection Systems; International Trends and Emerging Orientations. New York: Oxford University Press.

Smith L. (2012). FN's konvensjon om barnets rettigheter. I Høstmælingen N, Kjørholt ES, Sandberg K (red). 2012. BK. Barns rettigheter i Norge. 2. utg. Oslo: Universitetsforlaget. 


\section{Vedlegg:}

(fig 1: The Assessment framework, fra «Working Together» 2015, pkt 37)

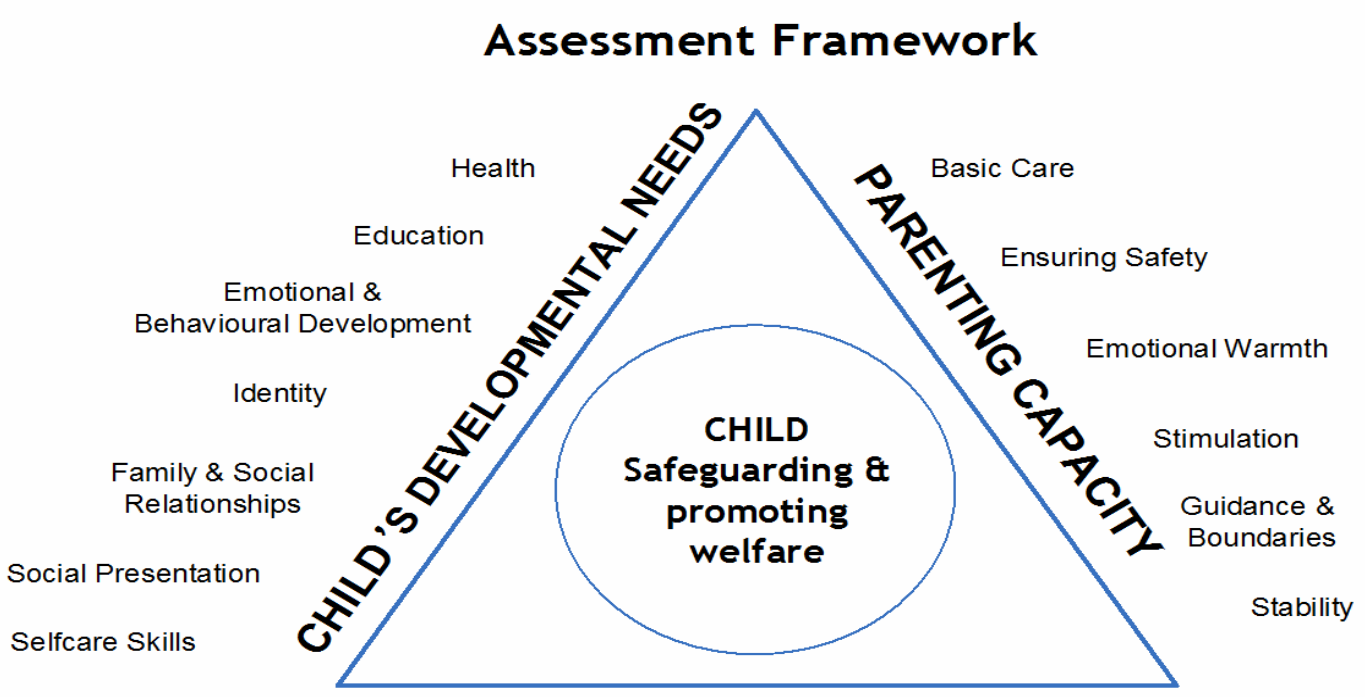

\section{FAMILY \& ENVIRONMENTAL FACTORS}
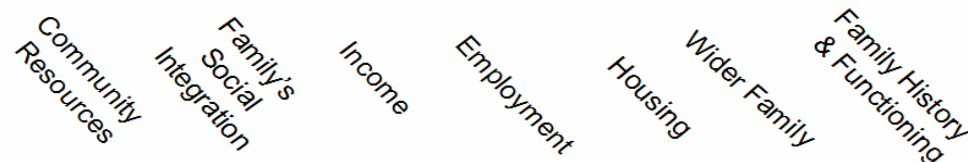